\title{
THE ROLE OF UNITED TERRITORIAL COMMUNITIES IN THE FUNCTIONING OF AGRICULTURAL ENTERPRISES
}

\author{
Balaniuk Ivan', Ihor Kozak ${ }^{2}$, Sergiy Balaniuk 4 , Iryna Kozak-Balaniuk ${ }^{5}$,Liudmyla Sas ${ }^{6}$, *Diana \\ Shelenko ${ }^{7}$
}

${ }^{1}$ Prof. Dr. Vasyl Stefanyk Precarpathian National University, 57, Shevchenka st. 76010, Ivano-Frankivsk, Ukraine, phone:+380503733282, e-mail: ifbalaniuk@gmail.com

${ }^{2}$ Prof. Dr. John Paul II Catholic University of Lublin, 14, Al. Ractawickie st. 20-950, Lublin, Poland, phone: +48604227996,e-mail: modeliho@kul.lublin.pl

${ }^{3}$ Vasyl Stefanyk Precarpathian National University, 57, Shevchenka st. 76010, Ivano-Frankivsk, Ukraine, phone: +48604227996,e-mail: modeliho@kul.lublin.pl

${ }^{4}$ PhD candidate Vasyl Stefanyk Precarpathian National University, 57, Shevchenka st. 76010, Ukraine, IvanoFrankivsk, phone: +380950561827, serhio088@gmail.com

${ }^{5}$ Dr. John Paul II Catholic University of Lublin, 14, Al. Ractawickie st. 20-950, Lublin, Poland, phone: +48605121058 , e-mail: irenakozak@gmail.com

${ }^{6}$ Prof. Dr. Vasyl Stefanyk Precarpathian National University, 57, Shevchenka st. 76010, Ivano-Frankivsk, Ukraine, phone:+380503714824, sas_lyudmyla@ukr.net

${ }^{7}$ Prof. Dr. Vasyl Stefanyk Precarpathian National University, 57, Shevchenka st. 76010, Ivano-Frankivsk, Ukraine, phone: +380990662326 e-mail: dianashelenko@ukr.net

Received 0101 2021; Accepted 01032021

\begin{abstract}
The article reveals the features of the balanced development of the United Territorial Communities (UTCs) in Ukraine which aims to create the preconditions for their stable growth and improvement of the quality of life in the countryside. The assessment of the role and of the level of satisfaction of the community from the operation of agricultural enterprises (AEs) in the united territorial communities is carried out. The results of the study have a theoretical and practical significance, especially in the context of non-endogenous development of rural areas, and may also serve as a tool for identifying the best economic solutions for the development of agricultural enterprises that function in UTCs.
\end{abstract}

Keywords: agricultural enterprises, decentralization, infrastructure, questionnaires, SWOT-analysis, territorial communities, united.

JEL Classification: Q130; O180; Q 120.

\section{Introduction}

Decentralization processes in Ukraine have resulted in the formation of united territorial communities (UTCs).
The development of rural territorial communities is considered as a process of forming the organizational and territorial environment of interaction of its elements, one of which is agricultural enterprises that conduct economic activities in their territory.

Copyright (C) 2021 Author(s), published by Vytautas Magnus University. This is an open access article distributed under the terms of the Creative Commons Attribution Non-Commercial 4.0 (CC BY-NC 4.0) license, which permits unrestricted use, distribution, and reproduction in any medium provided the original author and source are credited. The material cannot be used for commercial purposes. 
Therefore, one of the ways to achieve successful results of the newly created UTCs is a combination of a very territorial community and enterprises, i.e. the establishment of an effective mechanism of interaction taking into account the interests of both parties. That's why, the study of the processes of interaction between the united territorial communities and agricultural enterprises, in the context of decentralization, is relevant and timely.

The purpose of achieving the planned social and economic results of UTCs, which began their activities, is to establish cooperation with agricultural enterprises operating in their territory. To this end, it is necessary to determine the appropriate areas of such cooperation, which primarily requires a dialogue aimed at clarifying the real and potential aspects of cooperation, the expectations of the residents of the territorial community from the activities of agricultural formations. At present, this process is not yet established and requires consideration of scientific approaches for its implementation.

To the beginning of modern agrarian reform in Ukraine, agricultural enterprises had a relatively well-developed social and production base, which enabled them to support labour employment, gradually increase their wages, and, at their own expense, to train the necessary specialists and skilled workers. Besides, they kept not only their own, but also rural social infrastructure.

In the period from 1990 to 2000, collective agricultural enterprises were reorganized in Ukraine, in particular privatization of their estate has been carried out through the transfer of private property to the members of these enterprises. The objects of the social sphere of the village, which were held by enterprises, were not involved in privatization, but were transferred to the village councils for their maintenance. In the majority of cases, rural councils did not have enough funds to support the activities of these objects, most of them stopped functioning, and the rest did not fully correspond to its purpose.

Agricultural enterprises dispose of their own property or leased to which objects of the social sphere are largely non-owned. Their activities are mainly concentrated on the production of agricultural products, and the development of the social sphere remains, in most cases, out of sight, which, in particular, determines the low level of development of rural areas.

In this context, citizens' opinion about the role of the agricultural enterprises in their United Territorial Communities is of particular importance.

The economic crisis that continues in the agrarian sector of Ukraine stems from the macroeconomic issues, therefore overcoming it is possible due to the correct scientifically based state policy on food market regulation, as well as the promotion of effective integration of territorial communities. Moreover, Ukraine in 2017 had a relatively low rate $(30.8 \%)$ of the rural population (Demographics ..., 2018).

Historical experience shows that deep centralization in the management of the country and its economy is ineffective M. Chumachenko (1993). The absence of United Territorial Communities complicates the effective management of territories. As the society grows, the degree of decentralization of management increases.

In the scientific literature there is a comparative analysis of two models agricultural and rural development models D. Baldock, J. Dwyer, P. Lowe, J.-E. Petersen and N. Ward (2001). In the first agricultural model, the main role is played by agricultural workers. Their activity depends on the viability of rural areas and agriculture as the main function of the village. The second model, the development of rural areas. It presents different functions of rural areas. It should also be noted that A. Ragauskaite and J. Žukovskis (2020) see the future in the implementation of social innovations in rural areas, i.e. enterprises that operate there have the opportunity to share information, share responsibilities, functions and will be able to cooperate with existing resources.

Scientists pay attention to both the concepts of endogenous and exogenous development of rural areas. You can even note some departure from the exogenous and the emphasis on endogenous potential. For example, N. Ward (2005) suggests involving 
local resources in the development process. His driving force, he considers measures that begin from downward. Such an internal (endogenous) potential is also evaluated in the public sphere, in particular as the value of the social, spiritual and value of the rural formations itself.

This approach is very relevant for Ukraine. It enables the most efficient use and development of local potential of rural communities and international support, including with the EU.

In the time of dynamic changes and development of rural areas, due to different forms of co-financing, such a concept as nonendogenous development is essential. This term was introduced by Ch. Ray (2001), with the conviction that rural territories can build their own future, using their own potential. Ch. Ray (2010) also argues that local-based development can be realized both by local actors and by governments, as well as nongovernmental organizations whose range of influence combines global thinking with local action. The latest trend, related to nongovernmental organizations, is quite promising for the development of rural areas, as confirmed by the example of Poland and reflected in numerous scientific publications A. Borowska (2009), Z. Brodziński and A. Brodzińska (2014), M. Iwańska (2009), W. Knieć (2012), G. Zapsha and M. Sakhatskyi (2017), M. MichalewskaPawlak (2013), E. Pałka (2014).

Similar views on rural areas are also found in G. Bosworth and J. Atterton (2012), which point to the importance of the links between cultural, social and economic forms of their potential. At the local level, the positive development of territories depends on both the number of resources and the co-dependence between these forms of potential.

The volume of local resources affects the restoration of rural areas. After all, United Territorial Communities decide how to use a particular resource, especially one that differs from the resources of other neighbouring villages (in our sense of UTCs). The literature deals with the analysis of local resources and their use as public capital D. Damyanovic and F. Reinwald (2014), M. Murray and L. Dunn (1995), partnerships P. Cabus and W. VanHaverbeke (2003), N. Pylypiv, Yu. Maksymiv, and I. Piatnychuk (2018), K. McArdle (2012), migrations A. Stockdale (2005), (2006), rural tourism S. Everett and C. Aitchison (2008), A. Hashimoto and D. Telfer (2010), B. Lane and E. Kastenholz (2015), B. Su (2011); cultural heritage F. Fonseca and R. Ramos (2012), H. Hudeckova and A. Sevcikova (2007), T. Silva (2012), V. Yakubiv, and I. Boryshkevych (2018) etc.

The development of villages, as evidenced by the experience of highly developed countries, is a factor in stabilizing relations in the region and the state as a whole. The problems of the development of agricultural enterprises, which function in United Territorial Communities, are of particular importance today. Therefore, it is clear interest of scientists-economists in studying this problem.

But, despite the large number of scientific works, the development of theoretical and practical principles for the effective functioning of the AEs on the UTCs remains a subject of debate. Especially interesting in this context is the opinion of citizens about the activities of the agricultural enterprises in the territory of the United Territorial Communities.

The problem of UTCs associated with the functioning of the agricultural enterprises today is gaining importance. It relates to settlements that form United Territorial Communities and are associated with resource, human and financial support for these communities. This affects the ability of citizens who work and live on the territories of

Copyright (C) 2021 Author(s), published by Vytautas Magnus University. This is an open access article distributed under the terms of the Creative Commons Attribution Non-Commercial 4.0 (CC BY-NC 4.0) license, which permits unrestricted use, distribution, and reproduction in any medium provided the original author and source are credited. The material cannot be used for commercial purposes. 
settlements included in the UTCs. The opinion of citizens is important for the functioning of economic entities, among which the important role belongs to the agricultural enterprises. It is through assessing the opinions of citizens that you can learn the role of the AEs in the development of UTCs.

The aim of our investigation was to study public opinion about the main advantages and problems encountered by the agricultural enterprises that are conducting their activities in UTC; identifying areas for partnership cooperation and determine the main tendencies of their inhabitants. The purpose of our research was to:

(1) questioning of UTCs representatives in Ivano-Frankivsk region;

(2) definition of strategic directions of development of agricultural enterprises in UTCs by application of SWOT-analysis.

The aim of the article is to identify areas of partnership between the united territorial communities and agricultural enterprises, taking into account the aspirations of UTCs residents and the capabilities of enterprises.

\section{Research methods}

The information base of the research consisted of legislative and regulatory documents, statistics, questionnaires, works of domestic and foreign scientists on decentralization, operation and development of UTCs and enterprises.

In the course of the research the methods of comparison and generalization were used: questionnaires of UTCs and agricultural enterprises representatives, SWOT-analysis, expert evaluation and application of the SWOT-analysis matrix of formation of development strategy of agricultural enterprises in UTCs. The research has been carried out using general scientific methods, in particular: systematization, induction, deduction, analysis, synthesis in order to process the questionnaire materials and formulate conclusions.

A systematic approach to the study of the investigated issues has been applied, ie its consideration was carried out in the relationship and interdependence of the studied components - UTCs and agricultural enterprises.

A questionnaire survey of representatives of territorial communities about the activities of agricultural enterprises operating within the framework of this UTC has been conducted.

It should be noted that the covered the inhabitants of the United Territorial Communities in Ivano-Frankivsk region. Questionnaire survey is concerned with the indicators of agricultural enterprises' activity and their impact on the development of UTCs.

We have developed a questionnaire for UTCs and asked 80 people to answer 27 questions. Among them was a block of questions concerning address data (2 questions), sex-age category (2 questions). The next block was about organizational measures and consisted of 6 questions supporting cultural traditions, holding fairs and mass holidays to attract tourists from different regions to this territorial community, informational and advisory support of entrepreneurial activity, provision of agricultural products to communal institutions, receiving from AEs assistance for the development of UTC and the feasibility of establishing a new AE in the UTC.

The social block (5 issues) concerned the creation of new jobs for the inhabitants of the UTCs, providing them with administrative services, consolidation of labour resources in the territorial community by improving social infrastructure, social support of the population, its material interest in the work of the AEs.

Economic measures are characterized by answers to 8 questions regarding the transfer of income tax from agricultural enterprises to the budget of the UTCs; production and sale of ecological clean products; investments in agrarian production; ecological violations (pollution of reservoirs, soils, air) from the agricultural enterprises; assessing the reputation of enterprises in lending institutions and in UTC; fairness of fiscal policy, attraction of funds for roads repairing and maintenance of social institutions.

SWOT analysis of the conditions of their activity (Strengths, Weaknesses, Opportunities, Threats) has been carried out to 
justify the strategic plan for the development of the functioning of the AEs within the united territorial community. The essence of the SWOT analysis of strategic planning is to isolate and analyse these four categories V. Horbulin and A. Kachynskyi (2010).

The methodology research is basis on the fundamental principles of economics system comprehension of conditions and peculiarities of the development of agricultural enterprises in the UTCs.

The methods of comparison and generalization, questionnaires of representatives of UTCs and agricultural enterprises, SWOT-analysis, expert evaluation and application of the matrix of SWOTanalysis of the formation of strategy of development of AEs in UTCs were used for the investigation of the impact of united territorial communities in the functioning of agricultural enterprises.

Statistical processing of the data of 80 respondents makes it possible to analyse the results obtained within the limits of statistical error. Respondents were employees of 15 ( $60 \%$ of the total number of OTGs in the region). 4-6 employees from each UTCs took part in the survey (which amounted to a quarter of respondents). The choice of respondents for the survey from among UTCs employees is due to the fact that these individuals have the most reliable, complete and relevant information on the operation of enterprises, including agricultural, and their impact on community welfare. All this testifies to the representativeness of the sample of the study.

As a result of the study, the strengths and weaknesses, opportunities and threats of the impact of the agricultural enterprises on the development of UTCs were identified; developed a number of proposals for cooperation between them in order to achieve the maximum positive result for UTCs and the company have been developed.

\section{Research results and discussion}

In Ukraine, UTCs began to emerge from 2014. For example, in Ivano-Frankivsk region, the formation of United Territorial Communities began in 2015, when the first three communities have been created. In 2016, 5 more UTCs began the path of decentralization. At the beginning of 2020 there are 32 UTCs in Ivano-Frankivsk region Decentralization, (2020).

In accordance with the Perspective Plan of the Cabinet of Ministers of Ukraine in Ivano-Frankivsk region, 63 UTCs should be established in general. To achieve the desired results, a lot of efforts and a number of scientific formulations are needed.

The choice for the study of IvanoFrankivsk region is due to the presence in this administrative and territorial unit of five years of experience in the formation of UTCs, resulting in 25 UTCs were created, which is almost $40 \%(39.7 \%)$ of the planned number, as well as operating in their territory a significant number (317 units in 2018) of agricultural enterprises of various organizational and legal forms, which allowed for a qualitative and reliable analysis of the studied issues.

The analysis of the data obtained from the questionnaire shows that workers of UTCs in Ivano-Frankivsk region consist mainly of women, which account for $66 \%$ of the share and the reason of this is that men of working age go abroad for work.

The average age of the respondents is 42 years, mostly women. Only $21 \%$ of respondents are younger than 30 years old. Accordingly, from 31 to 40 years $-23 \%$, from 41 to 50 years $-20 \%$, from 51 to 60 years $17 \%$, from 61 years and more $-19 \%$. This indicates a low activity of young people.

More than $90 \%$ of the respondents indicated that agricultural enterprises operate on the territory of their UTCs, $9 \%$ say that there is no free agricultural area for

Copyright (C 2021 Author(s), published by Vytautas Magnus University. This is an open access article distributed under the terms of the Creative Commons Attribution Non-Commercial 4.0 (CC BY-NC 4.0) license, which permits unrestricted use, distribution, and reproduction in any medium provided the original author and source are credited. The material cannot be used for commercial purposes. 
entrepreneurial activity, $1 \%$ believe that there is no need for a agricultural enterprises. These questionnaires indicate that UTCs representatives see the future in the AEs, which can reduce unemployment and overcome the instability of social and economic development of the community.

Analysing issues that involve organizational measures, it should be noted that $64 \%$ of respondents believe that agricultural enterprises support the cultural traditions of the community. UTCs and agricultural enterprises take into account the traditions of agriculture in collective farms, as well as subsidiary farms of the previous historical period.

Conducting fairs and celebrations of religious holidays that popularize this UTC in the tourist market is also an event to support the cultural traditions of UTCs. This opinion is shared by $15 \%$ of respondents.

According to $48 \%$ of respondents, the information and advisory support of the business of the agricultural enterprises is intended to create a united space, in which, within the same premises, different authorities and structural units of the State Tourism Organization will be able to provide maximum administrative services to citizens and improve access to information.

On the question of the provision of services to the members of the UTCs by the agricultural enterprises - $75 \%$ of the respondents replied that such practice exists. Educational institutions are provided with local production in fresh or processed form (built meat canning and meat processing workshops, pasta lines, drying shops vegetables) $-45 \%$. Aid for the cultivation of private land plots by ASs technique is also provided $-20 \%$. Assistance is provided in the repair of cultural institutions, medical institutions, libraries, clubs $-10 \%$.

Today, $64 \%$ of AEs receive financial aid from UTCs, which is aimed at developing production and introduction of new types of products. The financing of new scientific and technological developments from the budget of UTCs is being implemented (for example, Broshniv-Osadskaya UTC provides the agricultural enterprises for the purchase and installation of equipment for the production of ecologically clean cheese products).

The feasibility of creating a new AEs in their UTC was supported by only $23 \%$ of the respondents. This is due to the fact that in this UTC both different organizational and legal forms of management, have already been operating or owners of land plots are processing their holdings independently as well as the lack of free agricultural land suitable for economic activity.

The positive opinion of the respondents regarding the expedience of the existence of the old and the creation of new agricultural enterprises is due to the tax revenues to the budget of the UTC from agricultural enterprises in the amount of $60 \%$ of the personal income tax, as well as $100 \%$ of the single tax payable by the payers of the IVth group (agricultural products producers (Budget Code ..., 2010).

When analysing issues that involve social activities, it should be noted that almost half of respondents believe that the consolidation of human resources in the UTCs is precisely due to the improvement of social infrastructure, however, $23 \%$ estimate this connection as a partial one.

Respondents say that AEs provide new jobs for only $25 \%$ of UTCs residents. This situation is due to the fact that the newly created AEs in most cases use modern technologies that require high productive equipment and a small number of employees. In the main, agricultural enterprises are engaged in the production of crop production, where the employment of workers is in the spring-summer and partly autumn period, so it is seasonal.

Wages in agricultural enterprises are paid on time and regularly, however, in the minimal, amount that rarely satisfy employees. Pointing out the material interest of AEs employees, $15 \%$ of respondents believe that wages and social protection are minimal, wages are paid seasonally, many types of work are mostly not mechanized.

Regarding the reputation of AEs in UTCs, more than half of respondents $(57 \%)$ indicate its high level; the rest $(22 \%$ of respondents) indicate that residents of UTC 
and potential investors do not always trust the AEs managers, and $21 \%$ do not have confidence at all. Increasing the interest of UTC residents in the long-term cooperation with agricultural enterprises is due to favourable conditions of bilateral partnership and the possibility of solving common problems within the UTC.

Providing attractiveness to investors during the crisis period is important for the Ukrainian economy. In general, UTCs, according to the results of $13 \%$ of respondents' answers, do not contribute to the sale of agricultural products, nor do they invest in agricultural production (18\%). More than half of the respondents $(51 \%)$ of UTCs workers believe that due to the lack of AEs on this territory, they spend more on procurement of products and only $18 \%$ consider this indicator to be significant.

Answering the question about the limitations and fairness of the fiscal policy of AEs, $44 \%$ of the respondents answered that it is fair, $37 \%$ objected, it and $19 \%$ believe that justice is absent at all.

Today, in Ukraine there is a need to provide the population of UTC with ecologically clean food products. Answering the question if its residents would buy ecologically clean products at a higher price of AEs located in this UTC, the $62 \%$ answered convincingly. Those, who answered 'no', $23 \%$ can not buy products because they are mostly sold in bulk; $8 \%$ - do not see the need for the manufacturing ecologically clean products, $7 \%$ - believe that it is expensive and for $4 \%$ it does not matter where the AE is located. The very satisfaction of population needs in safe and ecologically clean food products, which is emerging as an urgent issue for consumers, will attract attention to enterprises both from the population of this area and residents of neighbouring UTCs.

It should be noted that in relation to ecological violations (pollution of water reservoirs, soils, air) by agricultural enterprises, $35 \%$ of respondents expressed their concern about the current problem. Mainly they are worried about the depletion of soils by cultivating monocultures $-14 \%$, abuses of chemical soil cultivation $-14 \%$, interference with atmospheric conditions, by shooting clouds from guns or by releasing special chemicals $-4 \%$, and other factors $4 \%$. The UTC should provide the support of environmental equilibrium with minimal negative environmental impact in order to preserve the environment for future generations.

Available AEs play an important role in the development of UTCs due to the implementation of productive, economic and social function.

In order to ensure the proper functioning of territorial communities in Ukraine, a number of normative and legal documents have been developed that limit their creation and regulate further financial and economic activity, however: according to survey data of respondents, not all normative and legal acts are implemented.

The presented results of the surveys show the need of each territorial community in cooperation with agricultural enterprises in carrying out the following measures:

to outline ways of interaction with each individual agricultural enterprise on a partnership basis;

to plan a system of measures to support various agricultural enterprises by increasing the sales of their products through regional trading networks, as well as providing educational institutions, hospitals located on the territory of UTCs with products of their production (support is $66 \%$ );

to develop programs for obtaining credit resources $(57 \%$ of respondents believe that agricultural enterprises have a positive reputation in lending institutions); 
to coordinate actions that may affect the results of the work of the agricultural enterprises in the village (the share of employment of the UTCs population in the agricultural enterprise is $-85 \%$ );

to create a system of information support for business activities of AEs (data from the questionnaires indicate that almost half of respondents believe that this system is organized and promotes timely regulation of problems and prevention of violations in the future);

to stimulate the increase of social standards, as well as the level of wages in an agricultural enterprise (12\% of respondents consider it high, $53 \%$ average and $35 \%$ rather low);

to create conditions for increasing the competitiveness of agricultural enterprises (according to $55 \%$ of the respondents, agricultural producers have good knowledge of the market state and their competitors; however, $32 \%$ point to the lack of development of marketing services, and $12 \%$ note that agricultural enterprises do not have their potential customers and places on the market; the increase in competition from agroholdings is also noted $49 \%$ );

to approve the schedules of wholesale fairs where products of own production will be realized. This is needed to attract tourists and getting acquainted with familiarize activities of agricultural producers who work in UTC. According to the respondents ( $82 \%$ ) quality products of AEs are positioned as a 'visiting card' UTC;

to carry out repair of roads within the UTCs. $63 \%$ of respondents consider, that the unsatisfactory transport connection between settlements of UTCs effects on volumes of realization of agricultural enterprises products. Only $25 \%$ of respondents indicated that this factor was a partial influence;

to stimulate the opening of corporate shops of agricultural enterprises $(33 \%$ of respondents claim that their absence affects the sale of products in this UTC; $38 \%$ - in part);

to develop and implement programs for the conservation of land resources and environmental protection. A quarter of respondents indicate environmental violations by AEs, in particular pollution of water reservoirs, soils, air, and only $22 \%$ believe that this effect is insignificant).

The above mentioned positions are confirmed by the results of investigation of the development of agricultural enterprises in Ivano-Frankivsk region using SWOT analysis (Table 1).

In the process of SWOT-analysis of the impact of the AEs activities on UTCs, the quantitative advantage of weaknesses over strengths was established. This indicates that at the present stage of operation of agricultural enterprises there are some difficulties in their interaction with UTCs, and therefore there is a need to develop and apply a set of measures to neutralize existing drawbacks.

In order to maximize the strengths and influencing opportunities on the development of UTCs, to simplify the weaknesses and minimize the threats, a series of proposals have been developed by us for:

- creation of new centres of informational and consulting support of entrepreneurial activity;

- providing of conditions for social and economic growth of the AEs;

- identification of reserves for increasing the efficiency of agricultural production (due to increased production of ecologically clean output);

- satisfaction of social and economic interests of the representatives of UTCs;

- cooperation with employers;

- involvement of public organizations in the provision of information technology services.

Cooperation between UTCs and AEs in rural areas should be based on the principles of social partnership, which are closely linked to the market economy. Such a partnership is impossible without the unification and coordination of the efforts of all participants in the process.

Developed and scientifically based rules and regulations will encourage local authorities to:

- directing financial reserves to certain UTCs needs;

- stimulation of structural adjustment in the economy of UTCs; 
-creation of effective agricultural enterprises.

Based on the characteristics of weaknesses and threats from SWOT analysis, it follows that some obstacles hinder the development of the AEs, in particular:
- fiscal - high taxes for agricultural producers;

- social - insufficient provision by

agricultural enterprises staff;

-economic - low productivity of agricultural activity.

Table 1. SWOT analysis of the impact of AE activities on the development of UTC (developed by the authors)

\begin{tabular}{|c|c|}
\hline Strengths & Weak sides \\
\hline $\begin{array}{l}\text { 1. Providing jobs to the UTCs employment. } \\
\text { 2. Referral to the budget of the UTCs, where the registered } \\
\text { company, pays } 60 \% \text { of the income tax of individuals. } \\
\text { 3. Introduction of alternative types of heating of objects of } \\
\text { social sphere in UTCs. } \\
\text { 4. Supporting the community's cultural traditions. } \\
\text { 5. Providing educational and other institutions located on } \\
\text { the territory of UTCs with locally produced products at } \\
\text { reasonable prices. } \\
\text { 6. Providing technical assistance to UTCs (in winter - to } \\
\text { clean the area from snow; in spring and autumn - to help } \\
\text { the population in the cultivation of private land by } \\
\text { agricultural enterprises equipment). } \\
\text { 7. Charitable, sponsorship, material and technical } \\
\text { assistance of UTCs in the elimination of the consequences } \\
\text { of natural disasters; carrying out works on infrastructure } \\
\text { development, improvement of landscaping of settlements. }\end{array}$ & $\begin{array}{l}\text { 1. Low agricultural productivity. } \\
\text { 2. Technical and technological depreciation of fixed } \\
\text { assets of enterprises. } \\
\text { 3. Lack of branded stores. } \\
\text { 4. Insufficient development of organic production. } \\
\text { 5. Ecological disturbances (pollution of reservoirs, soils, } \\
\text { air). } \\
\text { 6. Depletion of soils due to the growth of monocultures. } \\
\text { 7. Uneven development of the structure of agricultural } \\
\text { enterprises production, in particular the decline of the } \\
\text { livestock industry. } \\
\text { 8. Insufficient financial, information and human resources } \\
\text { for modernization and technological renewal of } \\
\text { production. }\end{array}$ \\
\hline Opportunities & \\
\hline $\begin{array}{l}\text { 1. Availability of programs of state financial support for } \\
\text { the development of certain areas of agricultural activity, } \\
\text { mainly for small joint ventures. } \\
\text { 2. Opportunity to participate grant projects aimed at } \\
\text { agricultural development, which are financed from the } \\
\text { state budget and the budget of the European Union. } \\
\text { 3. Development of information infrastructure that } \\
\text { simplifies the search for the necessary information } \\
\text { (suppliers, customers, opportunities and areas of } \\
\text { modernization). } \\
\text { 4. Opportunities for labour cooperation with other joint } \\
\text { ventures in order to establish effective functioning. } \\
\text { 5. Signing of partnership agreements between agricultural } \\
\text { enterprises and UTCs. }\end{array}$ & $\begin{array}{l}\text { 1. Increased competition in the market. } \\
\text { 2. Migration of skilled labour. } \\
\text { 3. Frequent changes in legislation, imperfection of } \\
\text { legislation in the field of fair competition. } \\
\text { 4. Significant tax burden on the and their agricultural } \\
\text { enterprises, unfavourable lending conditions. } \\
\text { 5. Insufficient level of funding for targeted programs of } \\
\text { state support for agricultural enterprises activities and lack } \\
\text { of a comprehensive strategy for the development of the } \\
\text { agricultural sector. } \\
\text { 6. Weak development of public associations, the founders } \\
\text { of which are representatives of small agribusiness. }\end{array}$ \\
\hline
\end{tabular}

The SWOT matrix helps to identify the interrelationships between internal (strengths and weaknesses) and external (opportunities and threats) factors that are of strategic importance for the interaction of agricultural enterprises and UTCs.
All identified opportunities, threats, weaknesses and strengths are entered into the matrix. At the intersection of its elements, four fields are formed. In each of the fields, it is necessary to consider all possible paired combinations and identify those that need to be

Copyright (C 2021 Author(s), published by Vytautas Magnus University. This is an open access article distributed under the terms of the Creative Commons Attribution Non-Commercial 4.0 (CC BY-NC 4.0) license, which permits unrestricted use, distribution, and reproduction in any medium provided the original author and source are credited. The material cannot be used for commercial purposes. 
considered when developing a cooperation strategy.

Analysis of strengths and weaknesses, opportunities and threats made it possible to formulate the following conclusions:

- A significant part of UTCs residents work outside it, so it is necessary to maximally promote their involvement in agricultural enterprises in the UTCs and at the same time develop measures aimed at expanding production and diversifying the activities of the AEs. This, in turn, will create new jobs and reduce labour migration of the working population from the UTCs and the country;

- participation of agricultural enterprises in grant projects in the field of agriculture, financed from the state budget and the budget of the European Union, is expected to create opportunities for the development of agricultural enterprises and, accordingly, their positive impact on UTCs activities;
- in conditions of significant tax burden on agricultural enterprises, unfavourable lending conditions, lack or insufficient level of state financial support, significant dependence of agricultural activities on climatic conditions, there is a risk of decline of agricultural enterprises, which will negatively affect their interaction with UTCs.

The next step in the cross-sectional analysis is to determine the mutual influence of the strengths and weaknesses, opportunities and threats using the SWOT matrix of expert assessment of the interaction of the existing situation with events in the future (Table 2).

The expert evaluation showed a high mutual influence of the increase in agricultural production and the improvement of the production structure in agricultural enterprises for the development of UTCs.

Table 2. Expert evaluation of the interaction of UTCs and agricultural enterprises in IvanoFrankivsk region (Source: calculated by the authors)

\begin{tabular}{|c|c|c|c|c|c|c|c|c|c|c|c|c|}
\hline \multirow{3}{*}{ Strengths } & \multicolumn{12}{|c|}{ Mutual influence } \\
\hline & \multicolumn{5}{|c|}{ Opportunities } & \multicolumn{7}{|c|}{ Threats } \\
\hline & 1 & 2 & 3 & 4 & 5 & 1 & 2 & 3 & 4 & 5 & 6 & \\
\hline 1 & + & + & 0 & ++ & + & + & ++ & + & + & + & + & +12 \\
\hline 2 & - & + & -- & + & + & - & ++ & + & + & - & 0 & +2 \\
\hline 3 & + & ++ & 0 & 0 & + & 0 & - & + & + & + & -- & +4 \\
\hline 4 & 0 & + & + & + & + & 0 & 0 & 0 & + & 0 & 0 & +5 \\
\hline 5 & 0 & + & + & ++ & 0 & - & + & 0 & 0 & + & 0 & +5 \\
\hline 6 & -- & + & - & + & + & - & - & - & 0 & 0 & 0 & -3 \\
\hline 7 & - & 0 & 0 & + & + & 0 & - & - & + & 0 & + & +1 \\
\hline \multicolumn{13}{|l|}{$\begin{array}{l}\text { Weak } \\
\text { sides }\end{array}$} \\
\hline 1 & + & + & + & + & + & + & ++ & + & ++ & ++ & - & +12 \\
\hline 2 & + & 0 & + & + & 0 & + & 0 & + & ++ & + & - & +7 \\
\hline 3 & - & 0 & ++ & ++ & - & + & 0 & + & + & + & - & +5 \\
\hline 4 & ++ & + & + & - & - & + & 0 & + & + & ++ & -- & +5 \\
\hline 5 & -- & -- & 0 & 0 & + & + & 0 & + & + & + & 0 & +1 \\
\hline 6 & 0 & -- & - & 0 & + & + & 0 & + & + & + & 0 & +2 \\
\hline 7 & + & 0 & + & ++ & - & + & + & + & + & ++ & - & +8 \\
\hline \multirow[t]{2}{*}{8} & 0 & + & ++ & + & - & + & ++ & 0 & ++ & + & + & +10 \\
\hline & 0 & +6 & +6 & +14 & +5 & +6 & +7 & +8 & +16 & +13 & --5 & +76 \\
\hline
\end{tabular}

Notes: expert evaluation of mutual influence: ++ high mutual influence; + mutually influence; 0 neutral; - low mutual influence; - there is no mutual influence

As we can see in Table 2, threat n. 2 (Migration of skilled labour) has a high mutual influence $(++)$ on item 1 "Provision of jobs to the population of UTCs" and item 2 of the strengths individuals and paragraph n. 1 "Low productivity of agricultural activities" and paragraph n. 8 weak sides "Insufficient financial, information and human resources to modernize and technological renewal of production". 
For the development of labour cooperation with other agricultural enterprises in order to establish the effective functioning of the rural area of agricultural enterprises is appropriate, as shown in table 1 in the column "Opportunities" n. 4, to promote the creation of agricultural cooperatives, which will provide the opportunity to specialize production and increase its concentration, reduce material costs and as a result ensure the growth of agricultural production, which will have a positive provide an opportunity to specialize production and increase its concentration, reduce material costs and as a result ensure the growth of agricultural production, which will have a positive impact on the efficient functioning of UTCs.

Cooperation with other AEs in order to establish the effective functioning of $n .4$. in the column "Opportunities" will contribute to the provision of: jobs for the population of UTCs paragraph 1 "Strengths"; educational and other institutions located on the territory of UTCs products of local production at reasonable prices.
Clause 4. in the column "Opportunities" indicates the dependence on clause 3 and clause 7 in the column "Weak sides", which indicates the absence of branded stores and uneven development of the structure of AEs production, in particular the decline of the livestock industry.

Modern UTCs are interested in the support and development of agricultural enterprises in rural areas in order to address the social and economic problems of the area (Table 1, "Opportunities", n. 5), which is implemented through the signing of partnership agreements between agricultural enterprises and UTCs.

The imperfection of the management system and the low productivity of agricultural activities affect the entire financial and economic activities of AEs and their cooperation with UTCs.

The matrix, of SWOT-analysis of the level of satisfaction of citizens of UTCs with the functioning of agricultural enterprises in Ivano-Frankivsk region is given in (Table 3 ).

Table 3. Matrix of SWOT-analysis of the level of satisfaction of citizens of UTCs with the functioning of AEs in Ivano-Frankivsk region (Source: calculated by the authors)

\begin{tabular}{|c|c|c|}
\hline Opportunities and threats $\rightarrow$ & $\begin{array}{l}\text { POSSIBILITIES } \\
\text { 1. Diversification of activities, }\end{array}$ & $\begin{array}{l}\text { THREATS } \\
\text { 1. Low efficiency of the agricultural }\end{array}$ \\
\hline Strengths and weaknesses $\downarrow$ & $\begin{array}{l}\text { production, which creates the } \\
\text { preconditions for more complete } \\
\text { satisfaction of the needs of UTCs } \\
\text { residents. } \\
\text { 2. Partnership with AEs in } \\
\text { financing activities aimed at the } \\
\text { social development of UTCs. }\end{array}$ & $\begin{array}{l}\text { to carry out charitable and } \\
\text { sponsorship activities aimed at the } \\
\text { development of UTCs. } \\
\text { 2. Increased competition in the } \\
\text { market, including by agricultural } \\
\text { holdings), which creates the need to } \\
\text { find the AE competitive advantages, } \\
\text { in particular by developing small } \\
\text { market segments }\end{array}$ \\
\hline $\begin{array}{l}\text { STRENGTHS } \\
\text { 1. The ability to produce high- } \\
\text { quality agricultural products. } \\
\text { 2. Signing of partnership agreements } \\
\text { between AEs and UTCs. }\end{array}$ & $\begin{array}{l}\text { Creation of a strategy for the } \\
\text { development of agricultural } \\
\text { enterprises, based on which the } \\
\text { reputation of UTCs as a medium of } \\
\text { life for its employees and } \\
\text { consumers. This will facilitate the } \\
\text { interaction of the enterprise and the }\end{array}$ & $\begin{array}{l}\text { Formation the development strategy } \\
\text { of agricultural enterprises aimed at } \\
\text { improving their sectoral structure, } \\
\text { diversification of production. }\end{array}$ \\
\hline
\end{tabular}

Copyright (C) 2021 Author(s), published by Vytautas Magnus University. This is an open access article distributed under the terms of the Creative Commons Attribution Non-Commercial 4.0 (CC BY-NC 4.0) license, which permits unrestricted use, distribution, and reproduction in any medium provided the original author and source are credited. The material cannot be used for commercial purposes. 


\begin{tabular}{|c|c|c|}
\hline $\begin{array}{l}\text { 3. Growing demand among UTCs } \\
\text { residents for locally produced } \\
\text { agricultural products }\end{array}$ & $\begin{array}{l}\text { UTC with regard to investment, } \\
\text { technological upgrading and } \\
\text { modernization of agricultural } \\
\text { production. }\end{array}$ & \\
\hline $\begin{array}{l}\text { WEAK SIDES } \\
\text { 1. Low level of financing the } \\
\text { development of agricultural } \\
\text { enterprises (personnel, technology, } \\
\text { etc.). } \\
\text { 2. Presence of obsolete equipment in } \\
\text { agricultural enterprises. } \\
\text { 3. Reasonable prices for products } \\
\text { manufactured by the agricultural } \\
\text { enterprises for UTCs residents. }\end{array}$ & $\begin{array}{l}\text { Activation of work on attraction } \\
\text { funds in UTCs and creation of } \\
\text { charitable foundations for } \\
\text { realization of social and economic } \\
\text { projects, joint work on } \\
\text { infrastructure development, } \\
\text { improvement of settlements } \\
\text { improvement, roads, increase of the } \\
\text { level of provision of services to the } \\
\text { population and diversification of } \\
\text { production in accordance with } \\
\text { market needs. }\end{array}$ & $\begin{array}{l}\text { Formation of strategy for } \\
\text { optimization and energy saving, } \\
\text { reduction of unemployment level in } \\
\text { UTCs; creating conditions for } \\
\text { expanding the activities of existing } \\
\text { agricultural enterprises. } \\
\text { Formation and implementation of a } \\
\text { strategy for the preservation of clean } \\
\text { environments by creating an efficient } \\
\text { waste disposal system, reconstruction } \\
\text { of water supply and drainage systems. }\end{array}$ \\
\hline
\end{tabular}

Having studied the strengths and weaknesses of the influence of agricultural enterprises activity of Ivano-Frankivsk region on the development of UTCs capabilities and threats, we have drawn a parallel between these positions and discovered that with the help of strengths and opportunities, we can simplify and minimize the weaknesses and threats.

The matrix of SWOT analysis of the level of satisfaction of citizens of the UTCs with the functioning of AEs in IvanoFrankivsk region indicates that most of the opportunities can be realized by activating work on attraction of funds in the UTCs, creation of charitable foundations for realization of social and economic projects and joint work on infrastructure development that will enable minimize the weaknesses of the low level of financing for AEs development.

The partnership with AEs for financing activities is aimed at the social development of UTCs, modernization and improvement of production infrastructure. The result of these changes will be formed strategy: optimization and energy saving; reducing unemployment in UTCs and increasing the number of existing and newly created AEs, which will positively influence the further development of UTCs.

The release of special chemicals, soil depletion as a result of the cultivation of monocultures, are the most threatening factors affecting the vital functions of UTCs.

The strengths and opportunities include creating new jobs for UTC residents; replenishment of the revenue part of the budget with the unified tax of the IVth group and the personal income tax; carrying out joint measures to support and preserve the cultural traditions of the community; possibilities of production of ecologically clean products V. Boiko, L. Hnatyshyn (2020) creation of conditions for increase the volumes of production, its diversification.

The institutional and economic basis for the development of UTCs is formed, first of all, by AEs, most of which specialize in the production of agricultural products. The experience of highly developed countries shows that agricultural enterprises AEs are one of the stabilizing factors in the social and economic relations of the region as a whole.

In 2005, scientists V. Andriychuk, M Zubets and V Yurchyshyn (2005) noted the social and economic decline of the overwhelming number of villages and peasants in Ukraine. Today, this process has become considerably aggravated due to the departure abroad for earnings and living more than half of the industrious population (as shown by the results of our survey).

Such an approach in the future will contribute to further quantitative growth and development of $\mathrm{AE}$ and will positively affect the functioning of UTCs.

For the adoption of effective management decisions regarding the contemporary development of territorial communities it is expedient:

- to study the economic features of the regions, taking into account the use of resources available to them; 
- to ensure the expansion of their rights and real powers and increase the initiative and efficiency of the village workers;

- monitor the implementation of plans and programs for the development of UTCs.

Our recommendations confirm the opinion of T. G. Dudar (2010) that agricultural enterprises should participate in the formation of the social infrastructure of UTC on a partnership basis.

Having analysed the data obtained during the survey, we come to the conclusion that the stronger and more economically stable the agricultural enterprises, the better and more reliable will be the development of the territorial community around them, and vice versa.

We agree with the thesis that the goal of social and economic development of rural areas is to create UTCs that can provide decent income to its inhabitants and prevent depopulation and unemployment M. Stanny (2009). Accordingly, the level of social and economic development of a certain territory is determined by the components economic (level of the agrarian sector development and infrastructure, the level of balance in the labour market), social (demographic structure, education system, public activity) M. Stanny (2009).

\section{Conclusions}

The survey of the data of the conducted questionnaire made possible the following generalizations. The establishment and operation of agricultural enterprises has a social and economic significance for the UTCs, since the successful development of the agricultural enterprises, firstly, provides the creation of new jobs; secondly, maintenance of the UTCs infrastructure in an appropriate condition; thirdly, an increase in the volume of commodity production and the competitiveness of products on the market.

The matrix of the SWOT analysis of the satisfaction level of citizens of the UTCs with the functioning of the AEs in Ivano-Frankivsk region made it possible to determine by means of achieving the above-mentioned goals, and this, in particular: improving the production structure of AEs; establishment of partnership cooperation with UTCs to finance social development activities; working out of UTCs development strategy, the basis of which will be its reputation as a medium of life of employees of AEs and consumers of ecologically clean, agricultural products. It is emphasized on further interaction of enterprises with UTCs for investment, technological renovation and modernization of agricultural production.

The activation of the work of attracting funds from AEs and charitable foundations for the implementation of social and economic projects of UTCs should promote the development of infrastructure, improve the welfare of settlements, the development of roads in the UTCs, increase the level of service provision to the population and diversify production in accordance with market needs. Consequently, the stronger and more economically stable AEs will be, the better to develop and optimize the UTCs and vice versa.

The course on a consistent, voluntary association of territorial communities should create favourable conditions for the activation of AEs. The extension of the UTCs powers is directly linked to the development and support of AEs working in same territory, and also focuses on the demand and supply of the local market, that is, on the formation of social and economic climate on their places. 


\section{References}

Andriichuk, V. H., Zubets, M. V., Yurchyshyn, V. V. (2005). Modern Agrarian Policy: Problematic Aspects. [Suchasna agrarna politika: problemni aspekti] Kiev (Ukraine) Ahrarna nauka, 140 p.

Boiko V., Hnatyshyn L. (2020). Strategic priorities and mechanisms to stimulate farm enterprises development // Management Theory and Studies for Rural Business and Infrastructure Developmente. Vol. 42. No. 3: 350-358. https://doi.org/10.15544/mts.2020.35350

Balaniuk, I., Kozak, I., Shelenko, D., Balaniuk, S., Kozak-Balaniuk, I. (2019). Forecasting of Gross Agricultural Output of Agrarian Enterprises of Ukraine: Case Study with STELLA Software. // Economic Studies (Ikonomicheski Izsledvania). Vol. 28(5): 148-163.

Baldock, D., Dwyer, J., Lowe, P., Petersen, J.-E., Ward, N. (2001). The Nature Of Rural Development:Towards A Sustainable Integrated Rural Policy In Europe. A Ten-Nation Scoping Study for WWFand the GB Countryside Agencies, Countryside Agency, Countryside Council for Wales, English Nature and Scottish Natural Heritage, IEEP.

Borowska, A. (2009). Lokalne grupy działania czynnikiem stymulującym rozwój obszarów wiejskich w Polsce. // Acta Scientarium Polonorum Oeconomica Vol. 8. No. 4: 13-22.

Brodziński, Z., Brodzińska, A. (2014). Sektor społeczny i jego rola w stymulowaniu rozwoju obszarówwiejskich, Roczniki Naukowe. // Stowarzyszenie Ekonomistów Rolnictwa i Agrobiznesu, Vol. 16. No. 4: 52-56.

The Budget Code of Ukraine Information from the Verkhovna Rada of Ukraine [Bjudzhetnij kodeks Ukraïni Vidomosti Verhovnoï Radi Ukraïni] 08.07.2010 № 2456-VI. (average for the period). http://zakon3.rada.gov.ua/laws/show/2456-17/page4?text=60 [2018 09 08].

Cabus, P., VanHaverbeke W. (2003). The Economics of Rural Areas in the Proximity of Urban Networks: Evidence from Flanders // Tijdshrift voor Economische en Sociale Geographie, Vol. 94. No. 2: 230-245. https://doi.org/10.1111/1467-9663.00251.

Civil Code of Ukraine of 16.01.2003 № 435-IV. Official Internet portal of legal information (average for the period). - http://zakon2.rada.gov.ua/laws/show/435-15/page4. [2019 12 08].

Chumachenko, M. (1993). Problems of Regional Self-Government in Ukraine // Economy of Ukraine, Vol. 6. No. 379: 3-13.

Constitution of Ukraine [Konstitucija Ukraini] The Verkhovna Rada of Ukraine; Constitution, Law of 25.06.1996 № 254к / 96-BP. Official Internet portal of legal information. (average for the period). http://zakon3.rada.gov.ua/laws/show/254к/96-вр. [2019 08 10].

Damyanovic, D., Reiwald F. (2014). The "comprehensive village renewal programme in burgerland" as a means of strengthening the social capital in rural areas // European Countryside, No. 1: 18-35. - https://doi.org/10.2478/euco2014-0003

Decentralization reform of power in Ukraine (2020). [Detsentralizatsiina reforma vlady v Ukraini]. (average for the period). - http://decentralization.gov.ua/gromada [2020 11 10].

Demographics of Ukraine 2018. (2018). [Demografija Ukraini 2018]. Website Wikipedia. Official Internet portal of legal information (average for the period). - https://uk.wikipedia.org/wiki/Населення_України, [2020 07 10].

Dudar, T. H. (2010). Systemic Renewal of Rural Areas - Sustainable Development of the Agricultural Sector. Transformation of Agriculture and Rural Areas: Anniversary Collection of Scientific Articles. Lviv (Ukraine): LNAU: 77-85.

Everett, S., Aitchison, C. (2008). The Role of Food Tourism in Sustaining Regional Identity: A Case Study of Cornwall, South West England // Journal of Sustainable Tourism, Vol. 16. No. 2: $150-167$. https://doi.org/10.2167/jost696.0.

Iwańska, M. (2009). Rola organizacji pozarządowych w rozwoju obszarów wiejskich // Zagadnienia Doradztwa Rolniczego. No. 2: 62-71.

Fonseca, F. P., Ramos R. A. R. (2012). Heritage Tourism in Peripheral Areas: Development Strategies and Constraints // Tourism Geographies, Vol. 14, No. 3: 467-493.

Hashshimoto, A., Telfer D. (2010). Developing sustainable partnerships in rural tourism: the case of Oita, Japan. // Journal of Policy Research in Tourism, Leisure and Events, Vol.2. No.2: $165-183$. https://doi.org/10.1080/19407963.2010.482276.

Horbulin, V. P., Kachynskyi A. B. (2010). Strategic planning: solving national security problems Kyiv (Ukraine): NISD.

Hudečková, H., Ševčíková A. (2007). The renewal of the rural cultural heritage of the Czech Republic with the support of regional policy // Agricultural Economics, Vol. 53. No. 11: 505-512. - https://doi.org/10.17221/2676AGRICECON.

Knieć, W. (2012) Wspólna Polityka Rolna a zrównoważony rozwój obszarów wiejskich Polski, Wydawnictwo Naukowe Uniwersytetu Mikołaja Kopernika, Torun.

Lane, B., Kastenholz, E. (2015). Rural tourism: the evolution of practice and research approaches - towards a new generation concept? // Journal of Sustainable Tourism, Vol.23. No. 8-9: 1133-1156. https://doi.org/10.1080/09669582.2015.1083997.

Law of Ukraine "On voluntary association of territorial communities" from 05.02.2015. (average for the period). - http://zakon0.rada.gov.ua/laws/show/157-19. [2020 04 08]. 
McArdle, K. (2012). What makes a successful rural regeneration partnership? The views of successful partners and the importance of ethos for the community development professional // Community Development, Vol. 43. No. 3: 333-345. - https://doi.org/10.1080/15575330.2011.621211

Michalewska-Pawlak, M. (2013) Priorytety i wyzwania polityki rozwoju obszarów wiejskich Unii Europejskiej, Oficyna Wydawnicza ASPRA, Warszawa.

Murray, M., Dunn, L. (1995) Capacity Building for Rural Development in the United States // Journal of Rural Studies, Vol. 1, No. 1: 89-97.

Pałka, E. (2014). Rola lokalnych grup działania w rozwoju obszarów wiejskich. Przykład województwa świętokrzyskiego, Studia i Materiały // Miscellanea Oeconomicae Vol. 18. No. 3: 189-203.

Pylypiv, N. I., Maksymiv, Yu. V., Piatnychuk, I. D. (2018). Conceptual approach to construction of accounting and information provision of social responsibility for business enterprises through the prism of the business partnership system. Financial and credit activity: problems of theory and practice, Vol. 4. No. 27: $201-211$. https://doi.org10.18371/fcaptp.v4i27.154374.

Sakovska, O., Shpykuliak, O. (2019). State regulation of the functioning and development of agricultural cooperatives in the grain market // Proceedings of the 33rd International Business Information Management Association Conference, IBIMA 2019: Education Excellence and Innovation Management through Vision 2020. 33rd IBIMA Conference: 10-11 April 2019 Granada, Spain. Editor Khalid S. Soliman: 8316-8321. (average for the period). https://ibima.org/accepted-paper/state-regulation-of-the-functioning-and-development-of-agricultural-cooperatives-inthe-grain-market/ [2021 0308$]$.

Silva, T. (2012). Built heritage-making and socioeconomic renewal in declining rural areas: evidence from Portugal // Etnografica, Vol. 16. No. 3: 487-510. - https://doi.org/10.4000/etnografica.2091.

Stanny, M. (2009). Zróżnicowanie poziomu rozwoju obszarów wiejskich w Polsce a problem realizacji polityki spójności // Polityki europejskie, finanse i marketing, Vol. 1. No. 50: 48-89.

Stockdale, A. (2005). Incomers: Offering economic potential in rural England // Journal of the Royal Agricultural Society of England, No. 166: 1-5.

Stockdale, A. (2006). Migration: Pre-requisite for rural economic regeneration? // Journal of Rural Studies, No. 22: 354-366. - https://doi.org/10.1016/j.jrurstud.2005.11.001.

Su, B. (2011). Rural Tourism in China // Tourism Management, No. 32: 1438-1441. https://doi.org/10.1016/j.tourman.2010.12.005.

Vaskivska, K., Sembai, I. (2009). The functioning of agricultural enterprises in the context of rural development: scientific fundamentals, state and prospects: monograph. [Funkcionuvannja sil's'kogospodars'kih pidpriemstv u konteksti rozvitku sil's'kih teritorij: naukovi osnovi, stan i perspektivi] Lviv (Ukraine): PAIS. p. 196.

Ward, N., Atterton, J., Kim, T.-Y., Lowe, P., Phillipson, J., Thompson, N. (2005). Universities, the Knowledge Economy and 'Neo-Endogenous Rural Development' // Centre for Rural Economy Discussion Paper Series, No. 1: 115.

Zapsha, G. M., Sakhatskyi, P. M. (2017). Theoretical-methodical bases of estimation of management effectiveness of enterprise productive activity // Financial and credit activity: problems of theory and practice. Vol. 1, No. 22: 127-134. -https://doi.org/10.18371/fcaptp.v1i22.109938

Ragauskaitè, A., Žukovskis, J. (2020). Socialinių inovacijų vystymas, įtraukiant kaimiškų vietovių organizacijas. // Management Theory and Studies for Rural Business and Infrastructure Developmente. Vol. 42. No. 2: 214-220. https://doi.org/10.15544/mts.2020.21214

Yakubiv, V., Boryshkevych, I. (2018). Strategic analysis of the development of renewable energetics in the world and in Ukraine. // Journal of Vasyl Stefanyk Precarpathian National University. No. 5(3-4): 33-43.

Copyright (C) 2021 Author(s), published by Vytautas Magnus University. This is an open access article distributed under the terms of the Creative Commons Attribution Non-Commercial 4.0 (CC BY-NC 4.0) license, which permits unrestricted use, distribution, and reproduction in any medium provided the original author and source are credited. The material cannot be used for commercial purposes. 